\title{
Jo-1 autoantigen-specific B cells are skewed towards distinct functional $B$ cell subsets in anti-synthetase syndrome patients
}

Jennifer Young-Glazer ${ }^{1 \dagger}$, Alberto Cisneros II $^{1 \dagger}$, Erin M. Wilfong ${ }^{1,2}$, Scott A. Smith ${ }^{3,4}$, Leslie J. Crofford ${ }^{1,4}$ and Rachel H. Bonami ${ }^{1,4^{*}}$ (D)

\begin{abstract}
Background: Anti-Jo-1 autoantibodies which recognize histidyl-tRNA synthetase identify patients with the rare rheumatologic disease, anti-histidyl-tRNA synthetase syndrome (Jo-1 ARS), a phenotypically distinct subset of idiopathic inflammatory myopathies (IIM). Jo-1-binding B cells (JBCS) are implicated in disease pathogenesis, yet they have not been studied directly. We therefore aimed to characterize JBCs to better understand how they expand and function in Jo-1 ARS.
\end{abstract}

Methods: We enrolled 10 IIM patients diagnosed with Jo-1 ARS, 4 patients with non-Jo-1 IIM, and 8 age- and sexmatched healthy controls. We phenotypically characterized peripheral blood mononuclear cells (PBMCs) ex vivo using flow cytometry to define the B cell subsets in which JBCs reside. We further tested their ability to differentiate into antibody-secreting cells following stimulation in vitro.

Results: The majority of JBCs were $\operatorname{lgM}^{+}$(not class-switched). Compared to non-JBCs in the same donors, JBCs contained a higher percentage of autoimmune-prone CD21 ${ }^{10}$ cells and were increased in the $\mathrm{CD}_{2} 1^{\mathrm{lo}} \mathrm{IgM}^{+} \operatorname{lgD}{ }^{-}$ $C D 27^{+}$memory subset relative to healthy donor $B$ cells. Whereas non-JBCs were present in the anergic $B_{N D} B$ cell subset, JBCs were nearly absent from this compartment. JBCs were detected among plasmablasts in some donors, but a reduced frequency of JBCs differentiated into CD38 $24^{-}$plasmablasts compared to non-JBCs present in the same wells following in vitro stimulation.

(Continued on next page)

\footnotetext{
*Correspondence: rachel.h.bonami@vumc.org

${ }^{\dagger}$ Jennifer Young-Glazer and Alberto Cisneros III contributed equally to this work.

'Department of Medicine, Division of Rheumatology and Immunology, Vanderbilt University Medical Center, Medical Center North T3113, 1161 21st Avenue South, Nashville, TN 37232, USA

${ }^{4}$ Department of Pathology, Microbiology and Immunology, Vanderbilt University Medical Center, Nashville, TN 37232, USA

Full list of author information is available at the end of the article
}

C C The Author(s). 2021 Open Access This article is licensed under a Creative Commons Attribution 4.0 International License, which permits use, sharing, adaptation, distribution and reproduction in any medium or format, as long as you give appropriate credit to the original author(s) and the source, provide a link to the Creative Commons licence, and indicate if changes were made. The images or other third party material in this article are included in the article's Creative Commons. licence, unless indicated otherwise in a credit line to the material. If material is not included in the article's Creative Commons licence and your intended use is not permitted by statutory regulation or exceeds the permitted use, you will need to obtain permission directly from the copyright holder. To view a copy of this licence, visit http://creativecommons.org/licenses/by/4.0/. The Creative Commons Public Domain Dedication waiver (http://creativecommons.org/publicdomain/zero/1.0/) applies to the data made available in this article, unless otherwise stated in a credit line to the data. 
(Continued from previous page)

Conclusions: JBCs are enriched for autoimmune-prone $C D 21^{\mathrm{lo}} \mathrm{B}$ cells, some of which exhibit a memory phenotype in the peripheral repertoire of Jo-1 ARS patients. JBCS undergo limited class switch and show reduced capacity to differentiate into antibody-secreting cells. This suggests complex B cell biology exists beyond class-switched cells that differentiate to secrete anti-Jo-1 autoantibody (i.e., what is captured through serum autoantibody studies). New Jo-1 ARS therapies should thus ideally target non-Class-switched JBCs in addition to those that have undergone IgG class-switching to most effectively block cross-talk with autoreactive $T$ cells.

Keywords: Autoimmune diseases, B lymphocytes, Autoimmunity, Myositis

\section{Background}

The idiopathic inflammatory myopathies (IIMs) are multi-system rheumatologic disease processes involving inflammation of skeletal muscles that affect 2.4-33.8 per 100,000 persons worldwide [1]. Classically, patients have been categorized as having dermatomyositis or polymyositis based on the presence or absence of cutaneous disease. However, the IIM phenotype can be more precisely characterized by distinct autoantibodies that correlate with clinical manifestations and comorbidities [2-4]. One subset of IIMs is known as "anti tRNA synthetase syndrome" (ARS) due to autoantibodies that target specific tRNA synthetases. ARS manifestations frequently include interstitial lung disease, myositis, non-erosive arthritis, Raynaud's phenomenon, and skin rashes [5]. The most common anti-tRNA autoantibody in ARS patients is anti-histidyl-tRNA synthetase (Jo-1) which defines Jo-1 ARS [4]. Jo-1 autoantibody levels correlate with increased Jo-1 ARS disease severity [6]. Despite the value of anti-Jo-1 humoral responses in guiding clinical management decisions, the characteristics and phenotype of Jo-1-binding B cells (JBCs), anti-Jo-1 autoantibody precursors, have not been defined.

Although histopathologic studies have implicated $\mathrm{T}$ cell-mediated tissue destruction in muscle damage [7], evidence suggests autoreactive B cells play an important role in this process. Serum measurements of B cell activating factor of the tumor necrosis factor family (BAFF) are increased in patients with IIM and correlate with anti-Jo-1 autoantibody titers and disease activity severity $[6,8]$. B cell-targeting rituximab is commonly used to treat refractory ARS, and depletion of anti-Jo-1 autoantibodies correlates with clinical response [9, 10]. Clonal analysis of muscle-infiltrating B cells shows evidence of an antigen-driven immune response with somatic hypermutation, further providing evidence for B cell involvement in disease $[11,12]$.

The mechanism behind the immunologic response against the Jo-1 autoantigen and clinical manifestations of Jo-1 ARS is incompletely understood. Epitope heterogeneity suggests the mechanism is not simple molecular mimicry, but rather is directed against Jo-1 itself [13-15]. MHC class II haplotype and specific amino acids at particular positions within MHC class II molecules associate with Jo-1 autoantibody positivity $[16,17]$; thus, Jo-1 autoantigen presentation to $\mathrm{T}$ cells contributes to Jo-1 ARS pathogenesis. Autoantibodies in patient sera demonstrate affinity maturation over time, further supporting an antigen-driven humoral response against Jo-1 [18]. The membranebound $\mathrm{B}$ cell receptor (BCR) is not automatically secreted as antibody; thus, Jo-1 autoantibodies may not mirror the full spectrum of JBCs competent to present Jo-1 autoantigen to $\mathrm{T}$ cells.

In this study, we established a cohort of Jo-1 ARS patients and developed methods to identify JBCs by high-throughput ELISA and flow cytometry. We phenotypically characterized JBCs and identified specific B cell subsets that serve as reservoirs for antigen-specific $B$ cells. Given the identification of JBCs among both non-class-switched IgM and classswitched IgG populations, these data suggest the functional potential of JBCs as autoantigen-presenting cells should be considered independently of autoantibody production in monitoring expansion of autoreactive clones in disease, or alternatively their contraction as future experimental drug efficacy is assessed.

\section{Methods \\ Patient selection and clinical information}

Jo-1 ARS patients were selected from enrollees in the Myositis and Scleroderma Treatment and Investigative Center (MYSTIC) cohort at Vanderbilt University Medical Center as approved by the Vanderbilt Institutional Review Board. To capture all levels of disease severity, patients were recruited from outpatient rheumatology and pulmonology clinics, inpatient rheumatology and pulmonology consult services, and the intensive care unit. IIM patients were eligible for the study if they were 18 years or older and had been diagnosed with dermatomyositis or ARS by a rheumatologist or pulmonologist. Exclusions were pregnancy or HIV positivity. Twelve Jo1 ARS patients were enrolled. One subject was excluded due to having subsequent negative Jo-1 testing from a commercial source, and one patient was excluded due to 
recent administration of rituximab. Of the remaining 10 subjects, five had active disease and five were noted to have stable disease. "Active disease" was defined by having immunosuppression increased during their outpatient visit or requiring hospitalization due to lifethreatening disease. Subjects were defined as having "stable disease" if no medications were discussed during the encounter and current medications were either continued or de-escalated. Patients with active disease were typically earlier in their disease course with median enrollment 1.0 years after disease onset, while subjects with stable disease tended to have had the disease for a longer duration (median 13.8 years). Patients with active disease were typically being treated with high-dose steroids $(80 \%)$, while stable subjects were using alternative steroid-sparing treatments including azathioprine, hydroxychloroquine, IVIG, and leflunomide (100\%).

Four IIM subjects with alternative antibodies (anti-PL7, anti-EJ with anti-Ro52, anti-Mi-2, and anti-TIF1- $\gamma$ ) were used as disease controls. Healthy participants recruited from the community were eligible if they were 18 years or older, had no personal history or first-degree relatives with autoimmune disease, and had no history of malignancy treated with immunomodulatory therapy. Healthy controls were age- and sex-matched with stable and active Jo-1 ARS cases. As shown in Table 1, the median age of subjects with active disease and stable disease was similar at 53.8 and 57.1 years, respectively, while the healthy subjects were slightly younger with a median age of 48.2. Our Jo-1 ARS cohort was predominately female (80\%) and Caucasian (80\%). Clinical, laboratory, medication, and radiologic electronic medical record data were collected. Data were managed using the REDCap software system (Vanderbilt).

\section{Sample collection and processing}

Peripheral blood mononuclear cells (PBMCs) were obtained by collecting whole blood into mononuclear cell preparation tubes with sodium heparin (BD) via peripheral venipuncture. Cells were washed twice in PBS and red blood cells were lysed using Ack Lysis Buffer (Gibco). Cells were again washed in PBS and counted. Cells were cooled in $10 \%$ dimethyl sulfoxide (DMSO) in fetal bovine serum (FBS) at a rate of $-1{ }^{\circ} \mathrm{C} / \mathrm{min}$ until they reached a temperature of $-80^{\circ} \mathrm{C}$ for $24-72 \mathrm{~h}$. Cryopreserved PBMCs were stored in liquid nitrogen until the time of analysis and thawed with $\sim 80 \%$ viability. To collect serum samples, peripheral venipuncture was performed and blood was collected into serum collection tubes with silica act clot activator (BD). After complete coagulation, tubes were spun and serum was frozen in aliquots at $-80^{\circ} \mathrm{C}$ for future analysis.

Recombinant protein cloning, expression, and purification Online Supplemental Fig. S1 shows GST-Jo-1 fusion protein and GST-only (control) expression plasmids. Homo sapiens histidyl-tRNA synthetase (Jo-1), transcript variant 1 cDNA sequence (NM_002109.5) was purchased commercially (VB180802-1099xav, VectorBuilder) including an N-terminus GST-tag. The control vector was constructed similarly but only included the GST-tag sequence (VB181211-1124ant, VectorBuilder). Plasmids were transformed into BL21-CodonPlus (DE3)RIL competent cells (Agilent). GST-Jo-1 and GST were expressed following induction with $0.1 \mathrm{mM}$ IPTG for 16

Table 1 Study participant characteristics

\begin{tabular}{|c|c|c|c|c|}
\hline & Healthy controls $(n=8)$ & Non-Jo-1 IIM* $(n=4)$ & Stable Jo-1+ disease ${ }^{* *}(n=5)$ & Active Jo-1 disease ${ }^{* * *}(n=5)$ \\
\hline Age (years) & $48.2(42.1-52.0)$ & $58.2(50.9-63.2)$ & $57.1(43.4-57.4)$ & $53.8(46.2-56.1)$ \\
\hline Sex (female) & $5(63)$ & $3(75)$ & $5(100)$ & $3(60)$ \\
\hline \multicolumn{5}{|l|}{ Race } \\
\hline Caucasian & $6(75)$ & $4(100)$ & $5(100)$ & $3(60)$ \\
\hline African American & $1(13)$ & 0 & 0 & $2(40)$ \\
\hline Other ethnicity & $1(13)$ & 0 & 0 & 0 \\
\hline Disease duration (years) & - & $2(0.5-2.7)$ & $13.8(4.6-14.5)$ & $1.0(0.8-4.0)$ \\
\hline Daily steroid dose $\geq 20$ mg & - & $3(75)$ & 0 & $4(80)$ \\
\hline Other immunosuppressant use & - & $2(50)^{\dagger}$ & $5(100)^{\ddagger}$ & $1(20)^{\S}$ \\
\hline
\end{tabular}

Data are presented as medians (interquartile ranges) and counts (percentages) for continuous and categorical data, respectively

*Anti-PL-7, anti-EJ with anti-Ro52, anti-Mi-2, and anti-TIF1- $\gamma$

**Stable Jo-1+ anti-synthetase syndrome defined as having no medication changes discussed, and current medications either continued or de-escalated at the time of blood draw

***Active Jo-1+ anti-synthetase syndrome defined as either immunosuppression increased during outpatient visit, or patient hospitalized with life-threatening disease at the time of blood draw

${ }^{\dagger}$ IVIG (1), methotrexate (1)

${ }^{\ddagger}$ Azathioprine (3), hydroxychloroquine (1), leflunomide (1)

§IVIG (1) 
h at $25^{\circ} \mathrm{C}$ and affinity purified by Sepharose Glutathione beads (ThermoFisher). Online Supplemental Fig. S2 shows protein purity.

\section{ELISA}

Three hundred eighty-four-well ELISA plates (Maxisorp) were coated with $1 \mu \mathrm{g} / \mathrm{ml}$ purified GST-Jo-1 or GST protein in $1 \mathrm{X}$ PBS overnight at $4{ }^{\circ} \mathrm{C}$. Plates were blocked with $5 \%$ FBS in $1 \mathrm{X}$ PBS plus $0.5 \%$ Tween (1X PBS-T) at $25^{\circ} \mathrm{C}$ and washed $5 \mathrm{X}$ with $1 \mathrm{X}$ PBS-T. Plates were incubated at RT with 1:1000 patient sera or stimulated PBMC culture supernatants diluted 1:2 in blocking buffer. Parallel wells were incubated with 100X soluble GST-Jo-1 competitor during sera binding to measure specific binding. Bound antibody was detected by antihuman IgG Fc-specific-HRP (Sigma), anti-human IgGHRP, or anti-human IgM-HRP (Southern Biotech) secondary antibodies diluted in 5\% FBS/1X PBS-T. Plates were washed, TMB Ultra ELISA substrate (Thermo Fisher) was added, and plates were read at O.D. $370 \mathrm{~nm}$ using a microplate reader (SpectraMax M3).

\section{B cell stimulation}

Cryopreserved PBMCs were rapidly thawed, washed, and resuspended in ClonaCell-HY Medium A (StemCell). Cells were plated at a density of $0.033 \times 10^{6} \mathrm{cells} / \mathrm{ml}$ in Medium A with $0.833 \mu \mathrm{g} / \mathrm{ml}$ of $\mathrm{CpG}+0.133 \mu \mathrm{g} / \mathrm{ml}$ each of mouse-anti-human kappa and lambda antibodies (Southern Biotech). In addition, $0.033 \times 10^{6}$ cells $/ \mathrm{ml}$ viable gamma-irradiated NIH3T3 fibroblasts were added that had been genetically engineered to express cellsurface human CD40L and secrete human B cell activating factor (BAFF) and human IL-21. These stimuli drive $B$ cells to secrete $B C R$ as antibody to enable screening for antigen-specific B cells [19]. The mixture was then plated into 384-well flat bottom plates (Corning). Plates were incubated with $5 \% \mathrm{CO}_{2}$ at $37{ }^{\circ} \mathrm{C}$ and screened for the presence of anti-Jo- 1 antibody by ELISA on day 7, as described above.

\section{Flow cytometry}

Cells were stained for flow cytometry analysis using the following reactive antibodies and reagents: CD38-AF700 (HIT2), CD27-APC (O323), CD21-PcP-Cy5.5 (Bu32), CD24-APC-Cy7 (ML5), CD10-PE (HI10a), IgM-Pacific Blue (MHM-88), CD5-BV785 (UCHT2), CD3-BV510 (OKT3), CD14-BV510 (M5E2), CD16-BV510 (3G8), CD19-BUV395 (SJ25C1), IgG-PE-Cy7 (M131G05), and IgD-FITC (Ia6-2) (BioLegend, BD Biosciences, eBioscience, or Tonbo Biosciences). Jo-1 binding cells were identified through staining with GST-Jo-1 followed by detection with anti-GST-Texas Red (Abcam). Samples were acquired using a LSR II flow cytometer (BD Biosciences) and data were analyzed using FlowJo software (Tree Star). Flow cytometry samples identifying less than $20 \mathrm{JBC}$ events were excluded from downstream analysis of B cell subset composition. Non-JBC subset analysis was still performed for these donors.

\section{Statistical analysis}

All statistical analysis was performed using GraphPad Prism software version 8.3.1 (GraphPad Software). The resulting data are expressed as the mean frequency of the parent population \pm standard deviation. Differences across B lymphocyte populations for a given phenotype were tested using a Mann-Whitney $U$ test.

\section{Results \\ High-throughput screening detects JBCs in the peripheral blood of Jo-1 ARS patients with both inactive and active disease}

Our ELISA assay detects serum anti-Jo-1 IgG and distinguishes Jo-1+ disease from healthy control donors $\left(A_{370}\right.$ mean difference of $1.22 \pm 0.25, p<0.0001$, Fig. 1a). One subject did not have sera collected and was thus excluded. To confirm specificity of our ELISA assay, 4 IIM subjects with non-Jo-1 disease were also tested and were negative for anti-Jo-1 autoantibody (Fig. 1a). A GSTonly control produced minimal signal compared to GST-Jo-1 $\left(A_{370}\right.$ mean difference of $1.20 \pm 0.02, p<$ 0.0001 ), indicating signal was specific to the Jo-1 portion of the fusion protein. Fluorescence was reduced by a mean of $84 \%$ when 200 -fold excess competitor Jo-1-GST protein was co-incubated with patient sera, further demonstrating the specificity of the assay to detect anti-Jo-1 IgG (Fig. 1b). Inhibitable, Jo-1-specific IgM was also found in Jo-1 ARS patients, but not in IIM subjects with non-Jo-1 disease (Fig. 1a, b). These data show that Jo-1 autoantibody is produced by class-switched $\left(\operatorname{IgG}^{+}\right)$, as well as non-class-switched $\left(\operatorname{IgM}^{+}\right)$B cells in Jo-1 ARS patients.

To identify JBCs in the peripheral blood of Jo-1 ARS patients, we used a high-throughput method capable of capturing antigen-specific B cells as rare as 1 in 20 million cells [19]. This stimulation protocol drives $B$ cells to secrete the $B C R$ as antibody so that wells containing antigen-specific $B$ cells can be identified using ELISA screening. The majority of wells secreted immunoglobulin (99.9\%, Fig. 1c), including both IgG and IgM (99.9\%, Fig. 1c and Fig. S3). Figure $1 \mathrm{~d}$ shows identification of wells that contained JBCs using PBMCs isolated from two representative Jo-1 ARS patients. On average, 20.33\% of stimulated wells produced anti-Jo-1 autoantibodies (data not shown). Therefore, JBCs are present in the peripheral blood repertoire of these subjects. 


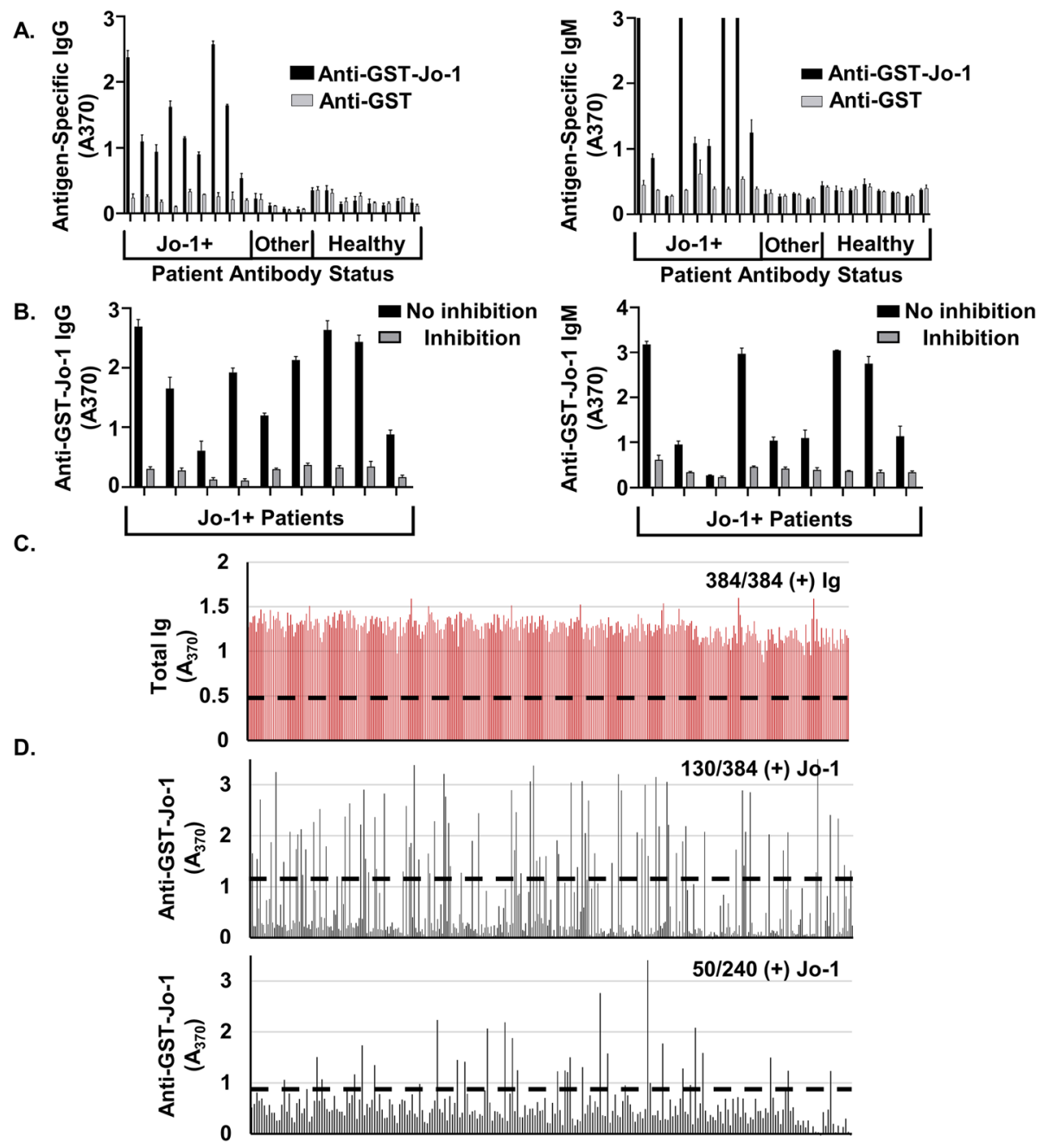

Fig. 1 Jo-1-specific antibody is detected in sera and stimulated PBMC cultures from subjects with Jo-1 ARS. Serum and PBMCs were collected from individuals with clinical laboratory-confirmed cases of Jo-1 ARS disease $(n=9)$, IIM patients with "Other Ab" (anti-PL-7, anti-EJ with anti-Ro52, anti-Mi-2, and anti-TIF1- $\gamma$ ), and healthy subjects $(n=8)$. a ELISA was used to measure serum IgG (left) or IgM (right) antibody bound to purified GST-Jo-1 fusion protein (black) and purified GST protein (gray). b ELISA was used to measure serum lgG (left) or lgM (right) antibody bound to GST-Jo-1 in the absence (black) or presence of excess soluble GST-Jo-1 competitor (gray) to detect Jo-1-specific autoantibody. c, d PBMCs collected from $n=5$ Jo-1+ subjects were separated into individual wells and polyclonally stimulated as in the "Methods" section to drive B cell differentiation into antibody-secreting cells. The fraction of positive wells is shown secreting $\mathbf{c}$ total antibody or $\mathbf{d}$ anti-Jo-1. $\mathbf{d}$ Results from two representative patients are shown. Dashed line defines positive wells with a mean fluorescence that is 3 standard deviations above the mean O.D. of all wells

The majority of JBCs are not class-switched but are found in both $\operatorname{lgM}^{+}$and $\operatorname{lgG}{ }^{+} B$ cell subsets in Jo-1 ARS patients with both stable and active disease

We next sought to measure the frequency of circulating JBCs in Jo-1 ARS patients and phenotypically characterize these cells ex vivo. In order to account for disease progression as a potential driving force behind cell phenotypic variation, we used flow cytometry to analyze PBMCs from Jo-1 ARS donors whose disease was progressing (active disease, $n=5$ ), donors whose disease is not progressing (stable disease, $n=5$ ), and healthy controls $(n=8)$. These samples were matched according to age and sex. JBCs were readily identified in a subset of Jo-1 ARS patients with active disease and stable disease, but not healthy controls (Fig. 2a, c). The majority of JBCs were $\operatorname{IgM}^{+}$(Fig. 2a, $\mathrm{d}$; mean $\pm \mathrm{SD}, 66.6 \pm 10.7 \% \mathrm{IgM}^{+}$vs $12.8 \pm 11.3 \% \mathrm{IgG}^{+}$; $p=0.0022$ ). We further measured the frequency of JBCs within $\operatorname{IgM}^{+}$and $\operatorname{IgG}^{+}$B cells. IgM ${ }^{+}$and IgG classswitched JBCs were observed in both stable and active disease patients (Fig. 2e, f).

JBCs are biased away from the anergic $B_{N D}$ subset but towards $\mathrm{CD} 21^{\text {lo }} \mathrm{B}$ cells

Peripheral immune tolerance can render autoreactive $B$ cells anergic in both mice and humans [20-23]. $\mathrm{B}_{\mathrm{ND}} \mathrm{B}$ cells $\left(\operatorname{IgD}^{+} \operatorname{IgM}^{\text {lo }} \mathrm{CD}^{2} 7^{-}\right.$, Table 2$)$ were shown 


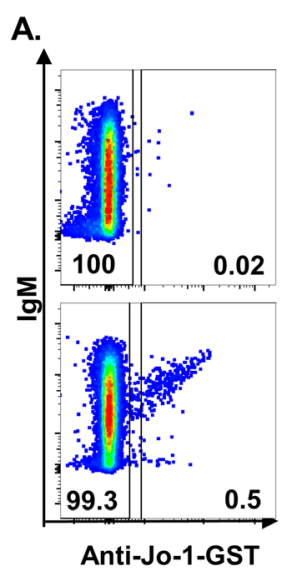

C.

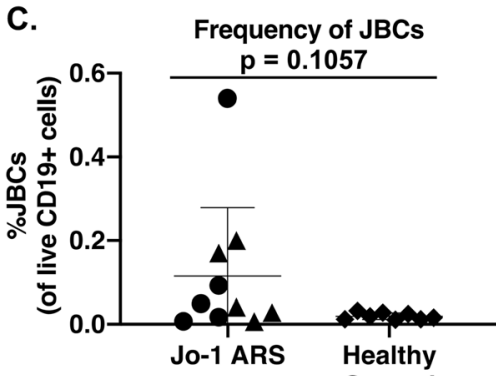

E.

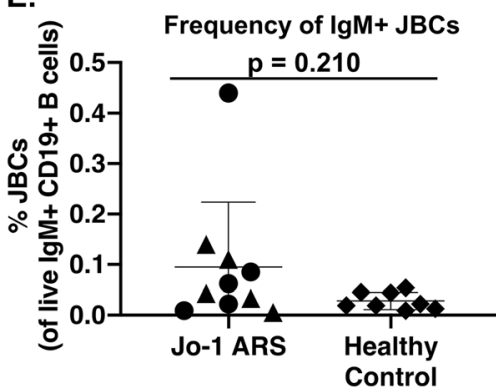

B.

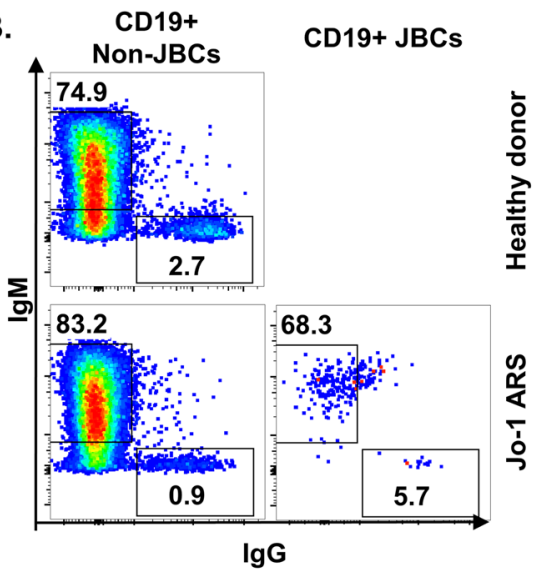

D.
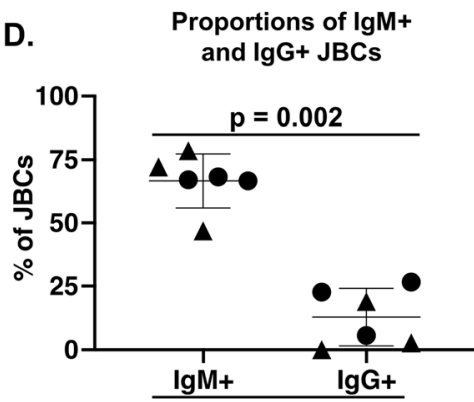

F.

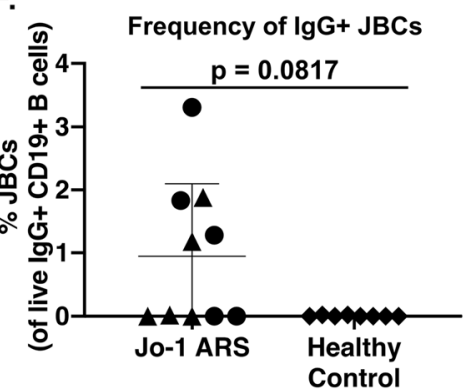

Fig. $2 \mathrm{JBCS}$ are detected among $\operatorname{lgM}^{+}$and $\operatorname{lgG}^{+} \mathrm{B}$ cells, with the majority being non-class-switched. PBMCs from healthy controls (top) or Jo-1 ARS (bottom) patients were stained and analyzed using flow cytometry. a Live, CD19+ ${ }^{+} D 5^{-} \mathrm{CD}_{14}^{-} \mathrm{CD} 16^{-}$cells were gated and anti-GST secondary antibody discriminated between Jo-1/GST-binding (Jo- $\left.1^{+}\right)$and non-JBCs (Jo-1 $\left.{ }^{-}\right)$B cells. b Cells were further gated on IgM versus IgG expression by non-JBC and JBC. Representative plots from healthy control and Jo-1 ARS donors are shown. c-f flow cytometry identifies the indicated populations among $n=5$ stable Jo-1 ARS (triangles), $n=5$ active Jo-1 ARS (circles), and $n=8$ healthy controls (diamonds). c JBCs were identified as in panel $\mathbf{a}$ and their frequency of total B cells was determined. $\mathbf{d}$ The $\operatorname{lgM}^{+}$or $\operatorname{lgG}^{+}$cell frequency (gated as in panel $\mathbf{b}$ ) of JBCs (gated as in panel a) is shown for Jo-1 ARS patients that had $>20 \mathrm{JBC}$ events $(n=6)$. e The frequency of JBCs within $\operatorname{lgM}^{+}(\mathbf{e})$ or $\operatorname{lgG}(\mathbf{f}) \mathrm{B}^{+}$cells is shown. Individual donors are plotted, and bars represent the mean \pm SD. $p$ values were determined using the Mann-Whitney $U$ test, and are indicated on each panel

previously to be functionally anergic $[24,25]$. We therefore investigated whether JBCs were enriched among this subset. JBCs were skewed away from the $B_{N D} B$ cell subset compared to non-JBCs or healthy control B cells (Fig. 3a, c; $0.22 \pm 0.55 \%$ versus $2.76 \pm$ $1.14 \% ; p=0.0009$ (non-JBCs) and $2.083 \pm 1.28 \% ; p=$ 0.0023 (healthy)).

CD21 ${ }^{\text {lo }} \mathrm{B}$ cells are a heterogeneous subset that have been reported to have functional properties of anergic, recently activated, or memory B cells [20, 26-29]. Previous studies showed increased IgM ${ }^{+} \mathrm{CD} 21^{\text {lo }} \mathrm{B}$ cells in rheumatoid arthritis (RA) and Sjögren's syndrome ( $\mathrm{SjS}$ ) patients $[20,30]$. We therefore investigated whether an increased frequency of $\mathrm{CD} 21^{\mathrm{lo}} \mathrm{B}$ cells was present among JBCs and compared Jo-1 ARS patients with healthy controls. Autoreactive-prone $\mathrm{CD} 21^{\text {lo }} \mathrm{B}$ cells are typically $\mathrm{IgM}^{+}$; however, $\mathrm{IgG}^{+} \mathrm{CD} 21^{\text {lo }} \mathrm{B}$ cells have also been identified $[20,27,30]$. JBCs and non-JBCs were identified in the same donor and the frequencies of $\mathrm{B}$ cell phenotypic subsets were compared (Fig. 3b). We found that JBCs contain 
Table 2 B cell phenotype definitions

\begin{tabular}{|c|c|}
\hline B cell type & Population phenotype \\
\hline JBCs & ${\mathrm{CD} 19^{+}}^{\mathrm{J}} \mathrm{J}^{-1-G S T^{+}}$ \\
\hline Non-JBCs & CD19 $9^{+}$Jo-1-GST \\
\hline $\mathrm{B}_{\mathrm{ND}}$ & $\mathrm{CD}_{19} \mathrm{CD}^{+} 27^{-} \lg \mathrm{D}^{+} \lg \mathrm{M}^{\mathrm{lo} /-}$ \\
\hline $\mathrm{CD} 21^{10}$ & $\mathrm{CD} 19^{+} \mathrm{CD} 21^{\mathrm{lo} /-}$ \\
\hline $\mathrm{CD} 21^{10} \mathrm{CD} 27^{+}$memory & $\mathrm{CD} 21^{\mathrm{lo}} \mathrm{CD} 27^{+} \lg \mathrm{D}^{-}$ \\
\hline Unswitched memory & $\mathrm{CD}_{19} \mathrm{CD}^{+} 7^{+} \operatorname{lgD}^{+} \operatorname{lgM}^{+}$ \\
\hline Switched memory & $\mathrm{CD} 19^{+} \mathrm{CD} 27^{+} \operatorname{lgD}^{-} \operatorname{lgM}^{-} \operatorname{lgG}^{+}$ \\
\hline IgM memory & $\mathrm{CD}_{19}{ }^{+} \mathrm{CD}_{27^{+}} \operatorname{lgD}^{-} \operatorname{lgM}^{+}$ \\
\hline Atypical memory & $\mathrm{CD}_{19}{ }^{+} \mathrm{CD}_{24^{-}} \mathrm{CD} 7^{-} \mathrm{CD}^{-} 8^{-} \mathrm{lgD}^{-}$ \\
\hline Transitional & $\mathrm{CD}_{19}{ }^{+} \mathrm{CD} 10^{+} \mathrm{CD} 24^{\mathrm{hi}} \mathrm{CD} 27^{-} \mathrm{CD} 8^{+} \operatorname{lgD}{ }^{+}$ \\
\hline Plasmablasts & $\mathrm{CD}_{19}{ }^{+} \mathrm{CD} 24^{-} \mathrm{CD} 38^{\mathrm{hi}}$ \\
\hline
\end{tabular}

All populations were additionally gated on live, singlet lymphocytes a higher proportion of $\mathrm{CD} 21^{\text {lo }} \mathrm{B}$ cells than non-JBCs (Fig. 3b, d, e; IgM, $p<0.01$ and IgG, $p<0.05$ ).

\section{JBCs are skewed towards CD21 ${ }^{\text {lo }}$ non-switched CD27 memory $B$ cells}

Memory B cells have complex phenotypes. We investigated memory markers among $\mathrm{CD} 21^{\text {lo }} \mathrm{B}$ cells as shown in Fig. $4 \mathrm{a}$ and $\mathrm{b}$ and previously described [31]. Unswitched CD21 ${ }^{\text {lo }}$ memory $\left(\mathrm{CD} 21^{\mathrm{lo}} \mathrm{IgM}^{+} \mathrm{IgD}^{+} \mathrm{CD} 27^{+}\right)$ $\mathrm{B}$ cells were decreased in JBCs when compared to healthy controls (Fig. 4c, $p<0.05$ ), though no difference was found between JBCs and non-JBCs $(p=0.54)$. $\mathrm{CD} 21^{\text {lo }}$ IgM only memory cells $\left(\mathrm{CD} 21^{\text {lo }} \mathrm{IgM}+\mathrm{IgD}-\right.$ $\mathrm{CD} 27+$ ) were increased in JBCs when relative to nonJBCs (Fig. 4d, $p=0.0312$ ), but not when compared to healthy control B cells $(p=0.18)$. No difference was observed in the frequency of IgG-switched CD $21^{\text {lo }}$ memory between JBCs and non-JBCs or healthy cells (Fig. 4e, $p=$ 0.54 (non-JBCs) and $p=0.32$ (healthy controls)).

No difference was observed between JBCs and nonJBCs or healthy donors for unswitched $\left(\operatorname{IgM}^{+} \operatorname{IgD}^{+}\right)$

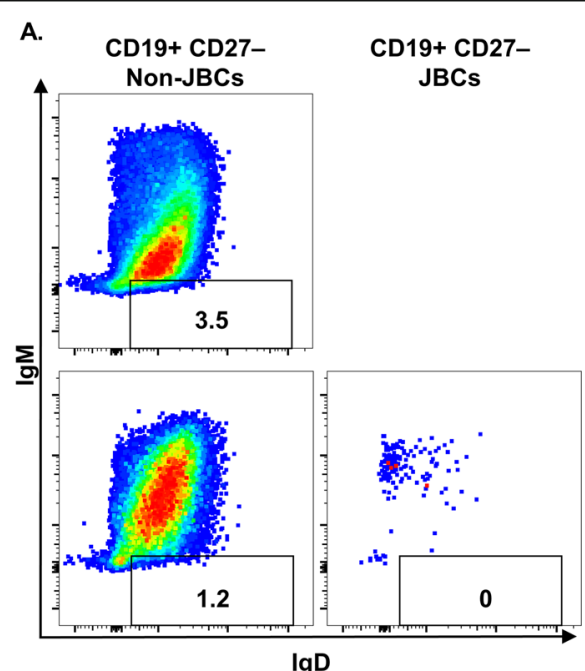

B.

CD19+ Non-JBCs CD19+ JBCs

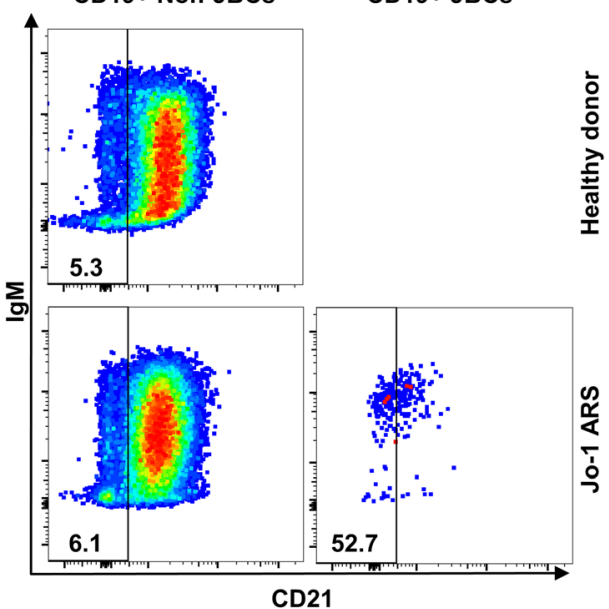

C. Proportion of B cells $p=0.0023$

D.

E. $\lg \mathrm{G}+\mathrm{CD} 2110$
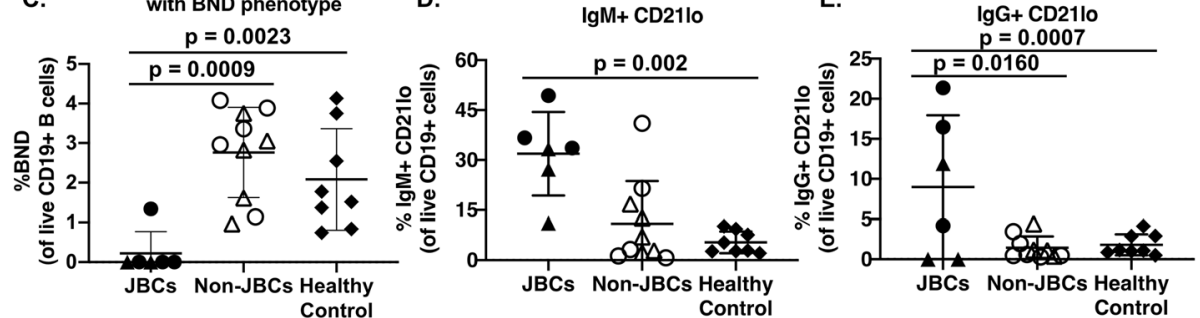

Fig. $3 \mathrm{JBCS}$ are enriched among $C D 21^{\mathrm{lo}}$, but not $\mathrm{B}_{\mathrm{ND}} \mathrm{B}$ cell subsets. PBMCs from healthy controls or Jo-1 ARS patients were stained and analyzed using flow cytometry. Live B cells were identified as in Fig. 2 and $\mathbf{a} \mathrm{B}_{\mathrm{ND}}\left(\lg \mathrm{M}^{\mathrm{lo}} \lg \mathrm{ID}^{-} \mathrm{CD} 27^{-}\right)$or $\mathbf{b} \mathrm{CD} 21^{\mathrm{lo}} \mathrm{B}$ cells were identified; representative plots are shown for healthy controls (top) or Jo-1 ARS patients (bottom). $\mathbf{c}-\mathbf{e} n=5$ stable Jo-1 ARS (triangles), $n=5$ active Jo- 1 ARS (circles), and $n=8$ healthy controls (diamonds). Only those Jo-1 ARS patients that had $>20$ JBC events $(n=6)$ were included for JBC sub-analysis. c The frequency of $B_{N D} B$ cells among JBCs and non-JBCs in Jo-1 ARS patients (identified as in Fig. 2) or from healthy donors is shown. $\mathbf{d}$, e CD21 ${ }^{\circ}$ B cells were further gated on $\mathbf{d} / \mathrm{IgM}^{+}$or $\mathbf{e} \mathrm{IgG}^{+}$cells and the frequencies of the indicated subsets are shown. Individual donors are plotted, and bars represent the mean \pm SD. $p$ values were determined using the Mann-Whitney $U$ test, and significant values are indicated on each panel 

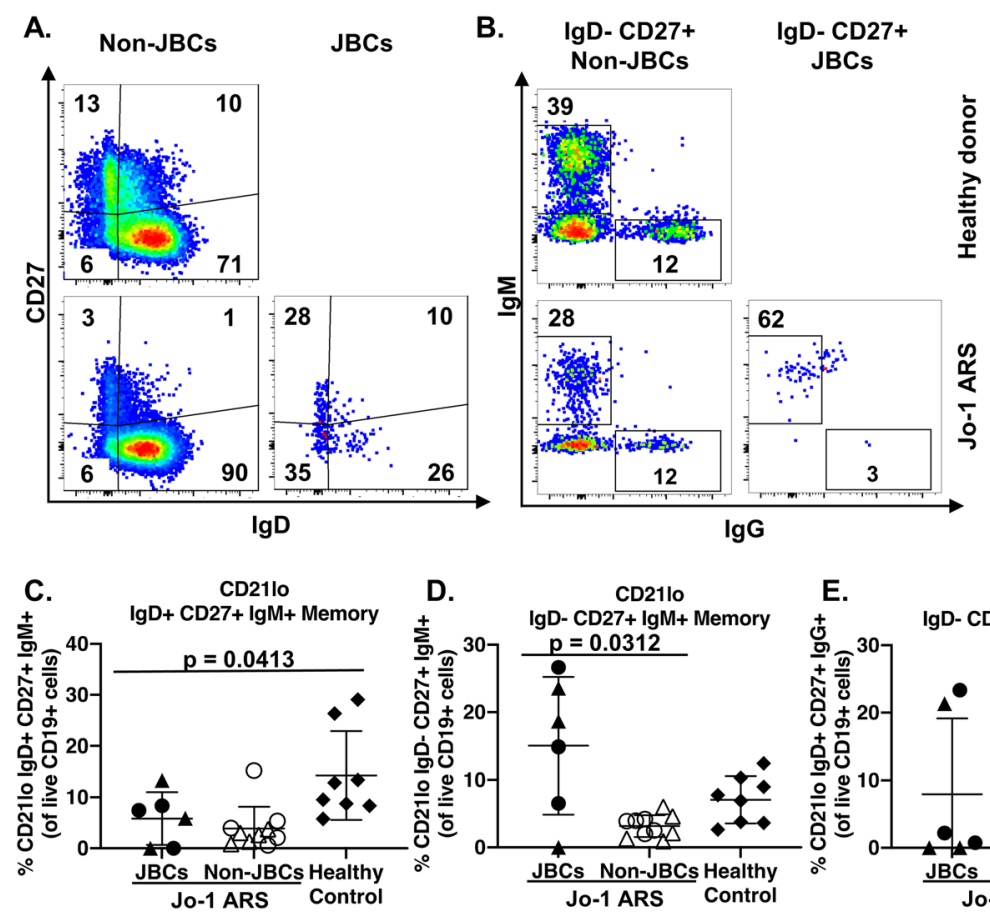

D.
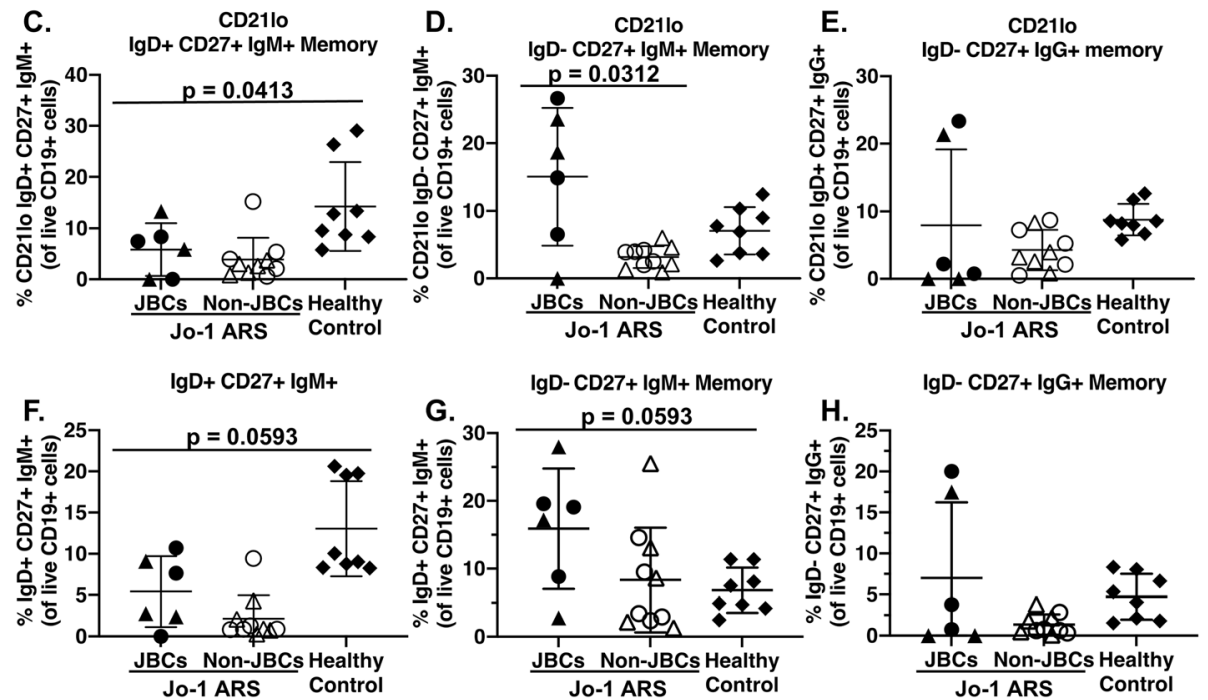

Fig. $4 \mathrm{JBC}$ are enriched among $\mathrm{CD} 21^{\mathrm{lo}} \mathrm{IgM}^{+}$memory cells. PBMCs from healthy controls (top) or Jo-1 ARS (bottom) patients were stained and analyzed based on IgD, IgM, IgG, and CD27 expression using flow cytometry. Live JBCs and non-JBCs (Jo-1 ARS) or total B cells (healthy donors) were identified as in Fig. 2. a, b Representative plots are shown for healthy control (top) or Jo-1 ARS (bottom) donors for the indicated markers. IgM and IgG expression was examined among $C D 27^{+}$IgD ${ }^{-}$cells gated as in panel $\mathbf{a}$. $\mathbf{c}-\mathbf{h}$ The indicated phenotypic subsets were examined in $n=5$ stable Jo-1 ARS (triangles), $n=5$ active Jo-1 ARS (circles), and $n=8$ healthy controls (diamonds). Only those Jo- 1 ARS patients that had $>20$ $\mathrm{JBC}$ events were included for JBC sub-analysis of either $\mathrm{CD} 21^{10}(\mathbf{c}-\mathbf{e})$ or all cells $(\mathbf{f}-\mathbf{h})$ for $\mathbf{c}, \mathbf{f} \operatorname{lgD}{ }^{+} \mathrm{CD} 27^{+} \operatorname{lgM} M^{+}, \mathbf{d}, \mathbf{g} \operatorname{lgD} D^{-} \mathrm{CD}_{2} 7^{+} \operatorname{lgM}{ }^{+}$, and $\mathbf{e}, \mathbf{h}$ $\lg D^{-} \mathrm{CD}_{2} 7^{+} \mathrm{IgG}^{+}$subsets. Individual donors are plotted, and bars represent the mean \pm SD. $p$ values were determined using the Mann-Whitney $U$ test, and significant values are indicated on each panel

memory (Fig. 4f, $p=0.15$ (non-JBCs) and $p=0.06$ (healthy controls)), $\operatorname{IgM}^{+} \mathrm{IgD}^{-} \mathrm{CD}^{2} 7^{+}$(Fig. $4 \mathrm{~g}, p=0.06$ (non-JBCs) and $p=0.09$ (healthy controls)), $\mathrm{IgD}^{-} \mathrm{CD} 27^{+}$ IgG $^{+}$(Fig. 4h, $p=0.6901$ (non-JBCs) and $p=0.55$ (healthy)), or $\mathrm{IgD}^{-} \mathrm{CD}^{-} 7^{-} \mathrm{CD} 24^{-} \mathrm{CD}^{-} 8^{-}$(Figure S4c) subsets. JBCs are therefore enriched for $\mathrm{CD}_{2} 1^{\mathrm{lo}} \mathrm{IgM}^{+}$memory $\mathrm{B}$ cells, a phenomenon that depends on autoantigen specificity of the $B$ cell, rather than general differences in donor skewing towards these B cell subsets.

\section{JBCs do not show transitional $B$ cell enrichment}

Fifty to $75 \%$ of transitional B cells (Table 2) are autoreactive, which are culled by immune checkpoints in healthy individuals [32]. These checkpoints function less efficiently in patients with autoimmunity, resulting in increased transitional B cells in the peripheral blood of patients with other rheumatic diseases [33-36]. To test whether a higher proportion of JBCs are transitional B cells in Jo-1 ARS, we measured this subset among JBCs and non-JBCs from the same Jo-1 ARS donors as well as healthy controls. While not significant, JBCs from Jo-1 ARS subjects trended towards having a higher frequency of transitional B cells relative to healthy controls (Fig. 5a, b, d, $3.3 \pm 5.4 \%$ versus $3.0 \pm 1.7 \%$; $p=0.41$ ).

\section{JBCs do not show plasmablast enrichment compared to non-JBCs or healthy donors}

B cells differentiate into short-lived plasmablasts during acute immune responses; thus, plasmablasts can contain a relatively high proportion of antigen-specific B cells 
A.

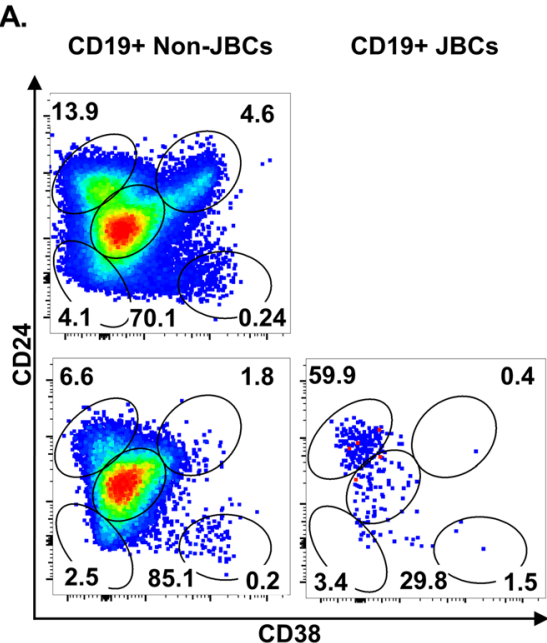

C.

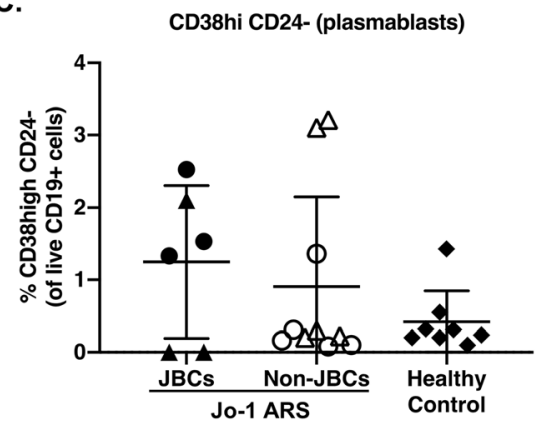

B. $\mathrm{CD} 19+\mathrm{CD} 24 \mathrm{hi}$ CD38hi Non-JBCs

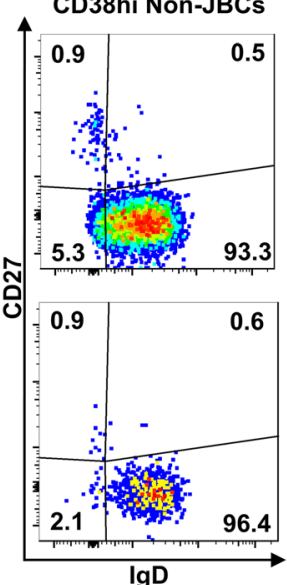

CD19+ CD24hi CD38hi

CD27- IgD+ Non-JBCs

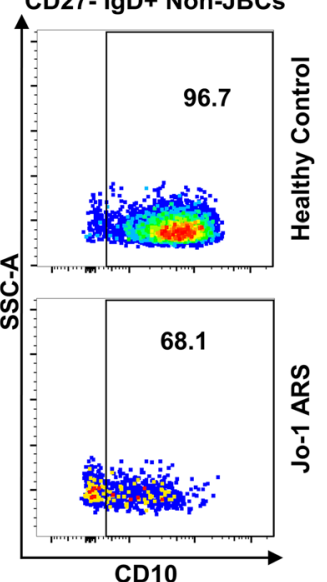

D.
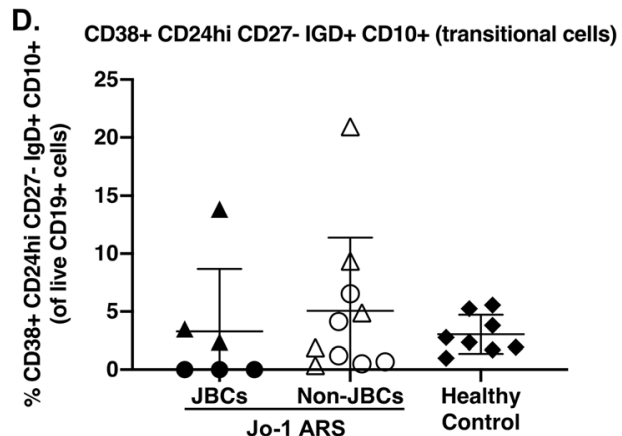

Fig. 5 JBCs are not increased among transitional B cells or plasmablasts. PBMCs from healthy controls (top) or Jo-1 ARS (bottom) patients were stained and transitional B cells (CD24 ${ }^{\text {hi }} \mathrm{CD} 38^{\text {hi }} \mathrm{CD} 27^{-}$IgD ${ }^{+} \mathrm{CD} 10^{+}$) or plasmablasts (CD24- CD38 ${ }^{\text {high }}$ ) were identified using flow cytometry. $\mathbf{a}, \mathbf{b}$ Representative plots are shown for healthy control (top) or Jo-1 ARS (bottom) donors for the indicated markers. b CD24 $4^{\text {hi }}$ CD $38^{\text {hi }}$ cells as gated in panel $\mathbf{a}$ are further gated on IgD/CD27 (left) and the resulting lgD ${ }^{+}$CD27 $7^{-}$cells are gated on CD10 (right). $\mathbf{c}$, $\mathbf{d}$ The indicated phenotypic subsets were examined in $n=5$ stable Jo-1 ARS (triangles), $n=5$ active Jo-1 ARS (circles), and $n=8$ healthy controls (diamonds). Only those Jo- 1 ARS patients that had $>20 \mathrm{JBC}$ events were included for JBC sub-analysis of $\mathbf{c}$ plasmablasts or $\mathbf{d}$ transitional B cells. Individual donors are plotted, and bars represent the mean \pm SD. $p$ values were determined using the Mann-Whitney $U$ test, and significant values are indicated on each panel

$[37,38]$. Given the importance of Jo-1 autoantibody in predicting clinical phenotype [4], we tested whether JBCs showed an increased frequency of plasmablasts $\left(\mathrm{CD} 38^{\text {hi }} \mathrm{CD} 24^{-}\right)$. Contrary to our expectations, the frequency of $\mathrm{CD} 38^{\mathrm{hi}} \mathrm{CD} 24^{-}$plasmablasts was not increased among JBCs relative to non-JBCs from the same donors, or healthy controls (Fig. 5a, c, JBCs versus non-JBCs, $p=0.93$ and healthy controls $p=0.39$ ). JBCs were found among IgM and IgG plasmablasts (not shown).

\section{A lower frequency of JBCs acquire a plasmablast phenotype following stimulation in vitro}

To test the functional capacity of JBCs, we stimulated PBMCs isolated from Jo-1 ARS patients with active disease as in Fig. 1 to drive their differentiation into antibody-secreting cells. After 6 days of stimulation, we used flow cytometry to determine the phenotype of JBCs versus non-JBCs from the same donors. Both $\mathrm{JBCs}$ and non-JBCs expanded following polyclonal
BCR stimulation (not shown). We identified JBCs and non-JBCs within wells derived from individual patients and compared the resulting phenotypic subsets across patients. Consistent with our ex vivo findings (Fig. 2), the majority of $\mathrm{JBCs}$ were $\operatorname{IgM}^{+}$following stimulation ( $p=0.0079$, Fig. 6a, b).

The proportion of $\mathrm{CD} 21^{\text {lo }} \mathrm{B}$ cells did not differ between JBC and non-JBC populations (Fig. 6c, d, IgM ${ }^{+}$ $\mathrm{JBCs}$ vs. $\operatorname{IgM}^{+}$non-JBCs, $p=0.42 ; \operatorname{IgM}^{-} \mathrm{JBCs}$ vs. $\mathrm{IgM}^{-}$non-JBCs, $p=0.84$ ). In vitro stimulation reduced CD21 expression across all $B$ cells, compared to CD21 levels on B cells ex vivo (not shown); thus, $\mathrm{CD} 21^{\text {lo }} \mathrm{B}$ cell differences could be masked in this setting. A comparison of relative frequencies for $\mathrm{CD} 19^{+}$ CD $38^{\text {hi }}$ CD24 ${ }^{-}$cells revealed a smaller proportion of cells with a plasmablast phenotype among JBCs relative to non-JBCs (Fig. 7a, b; $\operatorname{IgM}^{+} \mathrm{JBCs}$ vs $\operatorname{IgM}^{+}$nonJBCs, $p<0.0001)$, consistent with ex vivo findings (Fig. 55). This was also observed among $\operatorname{IgM}^{-}$(class- 
switched) cells (IgM- JBCs vs $\operatorname{IgM}^{-}$non-JBCs, $p<$ 0.0001). These stimulated populations contained a substantial proportion of $\mathrm{CD} 38^{\text {hi }}$ cells with intermediate $\mathrm{CD} 24$ expression, designated $\mathrm{CD} 38^{\mathrm{hi}} \mathrm{CD} 24^{\mathrm{mid}}$. A significantly larger proportion of $\mathrm{IgM}^{+} \mathrm{JBCs}$ expressed this phenotype when compared to $\operatorname{IgM}^{+}$non-JBCs (Fig. 7a, c; IgM ${ }^{+} \mathrm{JBCs}$ vs $\operatorname{IgM}^{+}$non-JBCs, $p=0.015$ ), indicating that while JBCs show less downregulation of CD24, most upregulate CD38 following in vitro stimulation (Figs. 6 and 7).

\section{Discussion}

In this study, we developed methods to identify JBCs and show they are present in the peripheral blood of patients with Jo-1 ARS among both $\operatorname{IgM}^{+}$and $\operatorname{IgG}^{+} \mathrm{B}$ cells. We find JBCs are enriched for CD21 ${ }^{\text {lo }}$ B cells, a subset that is globally elevated among total B cells in other rheumatic diseases $[20,39]$. Our samples were collected from patients with differences in disease severity, including patients requiring hospitalization and intensive care that would not be captured by outpatient enrollment. The ability to compare between JBCs and the remaining non-JBC repertoire within the same patient reduces the influence of confounding variables such as sex, age, ethnicity, individual immune variation, and treatment effects. Targeting autoantigen-specific $B$ cells was successfully applied to mice to prevent autoimmune disease and is an attractive strategy to treat human autoimmunity [40, 41]. JBCs are thus putative therapeutic targets in Jo-1 ARS. Overall, these data advance the understanding of antigen-specific B cell biology in Jo-1 ARS by extending their potential autoimmune contributions beyond IgG class-switching and antibody production.

We detect $\operatorname{IgM}^{+} \mathrm{JBCs}$ in peripheral blood, which is consistent with ARS/IIM patient muscle biopsy findings
A.

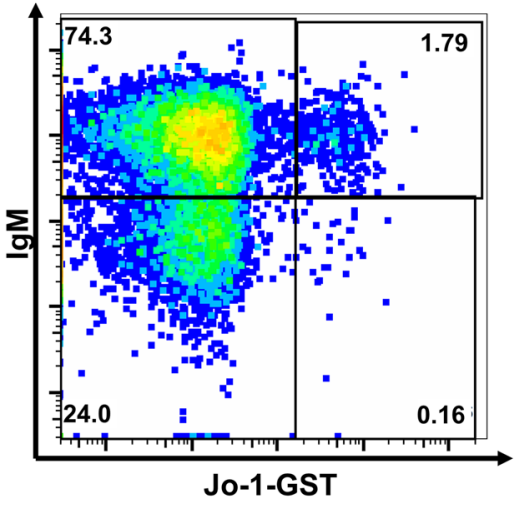

C.

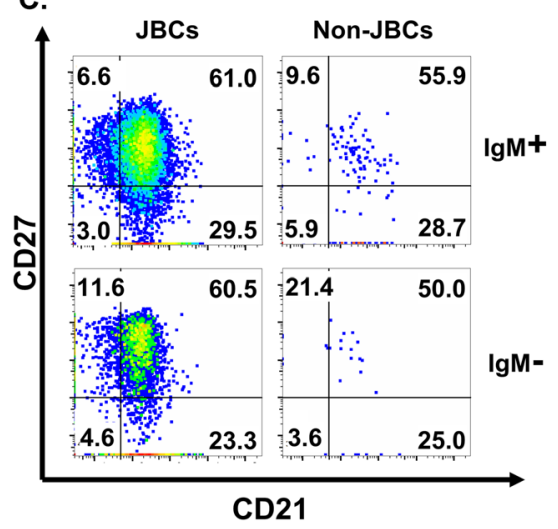

B.

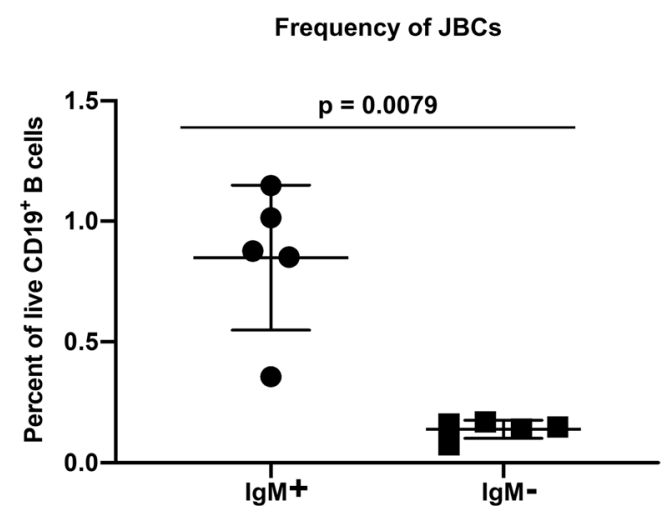

D.

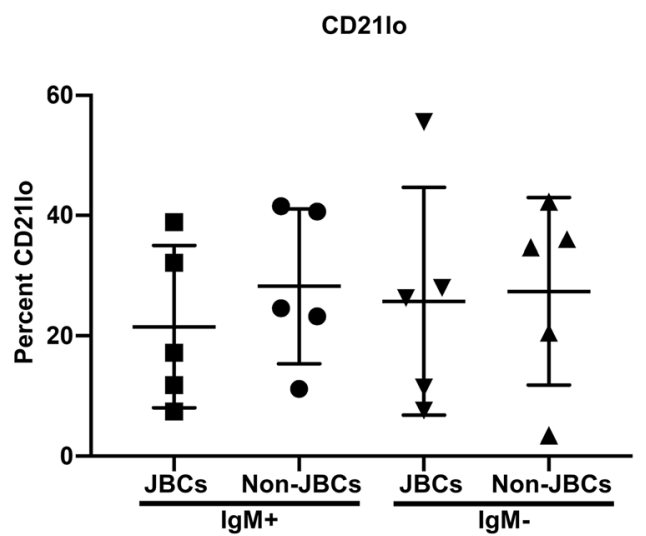

Fig. $6 \mathrm{JBCS}$ are identified following stimulation in vitro but are predominantly $\operatorname{lgM}^{+}$(non-class-switched). PBMCs from Jo-1 ARS patients with active disease were stimulated as described in the "Methods" section. Cultured cells from 40 to 60 wells per patient were harvested on day 6 and stained for flow cytometry analysis. a Representative pseudocolor plots describing the gating strategy are shown for the selection of live, CD19+ $\mathrm{IgM}^{+/-}$Jo-1 binding populations. The frequencies for each of these plots are indicated. $\mathbf{b}$ Cells were gated on live, CD19+ JBCS and the mean frequency of $\mathrm{IgM}^{+}$and $\mathrm{IgM}^{-}$cells was calculated per donor; individual donors are plotted. c Pseudocolor plot depicting the CD21 ${ }^{\circ} \mathrm{B}$ cells in $\mathrm{JBCs}$ and non-JBCs. $\mathbf{d}$ The mean frequency of $\mathrm{CD} 21^{\circ} \mathrm{B}$ cells within the indicated populations was calculated for per donor and individual donors are plotted. Statistical significance between populations as calculated using the Mann-Whitney $U$ test is indicated. Bars indicate the mean \pm SD 
A.

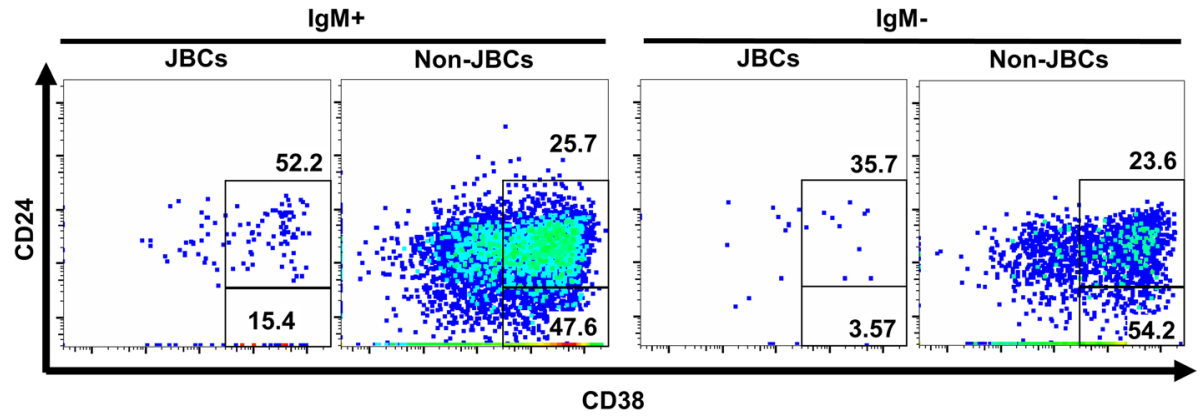

B.

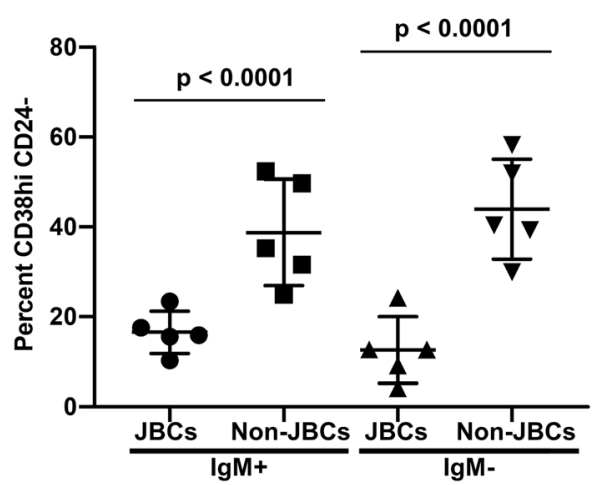

C.

CD38hi CD24mid

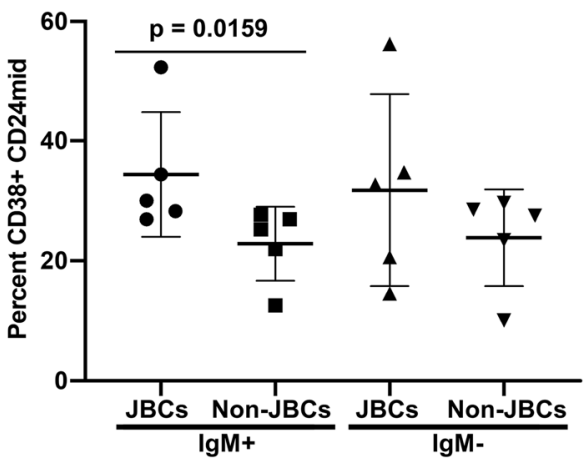

Fig. 7 A lower frequency of JBCs acquire a plasmablast phenotype following stimulation in vitro compared to non-JBCs from the same Jo-1 ARS patients. PBMCs from $n=5$ Jo-1 ARS patients with active disease were polyclonally stimulated as in the "Methods" section. Cultured cells from $n=$ 40-60 wells per patient were harvested on day 6 and stained for flow cytometry analysis. a CD24 and CD38 expression is shown in representative flow plots derived from a single well of stimulated PBMCs. Comparison of mean frequencies of $\mathbf{b} C D 38^{\text {hi }}$ CD24- $B$ lymphocytes or $\mathbf{c} C D 38^{\text {hi }}$ $\mathrm{CD} 24^{\text {mid }} \mathrm{B}$ lymphocytes between $\mathrm{JBC}$ and non-JBC populations. Significant differences between $\operatorname{IgM}^{+} \mathrm{JBC}_{\mathrm{B}}$ and $\lg \mathrm{M}^{+}$non-JBC or $\lg \mathrm{M}^{-} \mathrm{JBC}$ and $\operatorname{lgM}^{-}$non-JBC populations as calculated using Mann-Whitney $U$ test are indicated. The data are represented as the mean for each population within a given stimulation, and the bars indicate the mean \pm SD

that suggest IgG class switch and terminal differentiation of JBCs occurs at the site(s) of attack [11, 12, 42]. The majority of JBCs identified in peripheral blood had not undergone class switch. Tetanus toxoid responses in hyperimmunized individuals also skew towards IgM in the peripheral blood; tetanus toxoid-specific $\mathrm{B}$ cell enrichment is primarily observed among $\mathrm{IgG}^{+} \mathrm{B}$ cells proximal to vaccination and does not persist [43]. We identified 5/10 Jo-1 ARS patients that had clear IgG ${ }^{+}$ JBCs in peripheral blood, ranging from 1 to $3 \%$ of total $\mathrm{IgG}^{+} \mathrm{B}$ cells; this population was found in both stable and active disease patients. This suggests class-switching is likely ongoing in Jo-1 ARS disease and is not restricted to a rare immune tolerance breach event resulting in a clonal burst of IgG-switched JBCs. This finding suggests that IgG class-switching of JBCs is not restricted to tissue and/or that they exit tissues to recirculate after undergoing IgG class switch.

Defective tolerance checkpoints allow increased escape of autoreactive B cells from the bone marrow into the transitional compartment in the periphery in multiple autoimmune diseases, including RA, SjS, type 1 diabetes, and systemic lupus erythematosus (SLE), thereby increasing the probability of developing autoantibodies [33-36]. In juvenile dermatomyositis, immature transitional B cells are expanded in patients with active disease and have an inflammatory phenotype with high interferon alpha and TLR7-pathway signals [44]. Whereas one patient with severe disease shows an elevated percentage of transitional B cells among JBCs, a larger Jo-1 ARS patient cohort will be required to ascertain the extent to which the developmental block observed in other autoimmune diseases impacts JBCs in Jo-1 ARS.

Autoantigen-binding $B$ cells are absent from the anergic $\left(\mathrm{B}_{\mathrm{ND}}\right) \mathrm{B}$ cell compartment in pre-diabetic and newonset type 1 diabetes subjects and autoimmune thyroid disease patients, suggesting escape from this tolerant state is a harbinger of fulminant autoimmunity $[45,46]$. Furthermore, loss of $B_{N D} B$ cells in type 1 diabetes donors is associated with high-risk MHC class II alleles, suggesting interaction with $\mathrm{T}$ cells is involved in this process [46] and that $B_{\mathrm{ND}} \mathrm{B}$ cells may regain 
functionality to present antigen to T cells. JBCs are not skewed towards the anergic $\mathrm{B}_{\mathrm{ND}}$ subset, suggesting anergy, a mechanism of peripheral tolerance, is not a major force governing JBCs. The $\mathrm{B}_{\mathrm{ND}}$ compartment is not globally absent in Jo-1 ARS patients; non-JBCs show a similar frequency of $\mathrm{B}_{\mathrm{ND}}$ cells compared to healthy controls. This suggests specific factors, rather than global host defects, are overriding anergic programming for JBCs.

CD $21^{\text {lo }} \mathrm{B}$ cells have complex biology. In RA patients, $\mathrm{CD} 21^{\text {lo }} \mathrm{B}$ cells have anergic properties [20]. In the context of immunization, $\mathrm{CD} 21^{\text {lo }} \mathrm{B}$ cells exhibit properties that suggest they recently exited germinal center reactions and have transcriptional programs that indicate they are poised for plasma cell differentiation [26]. Such activated $\mathrm{B}$ cells can drive cognate $\mathrm{T}$ cell activation and acquisition of effector function. $\operatorname{IgM}^{+} \mathrm{CD} 21^{\mathrm{lo}} \mathrm{B}$ cells are autoreactive-prone [20,34] and are increased in the peripheral blood of SLE, RA, and SjS patients [26, 47, 48]. Compared to B cells isolated from healthy individuals, a higher fraction of JBCs from Jo-1 ARS patients had a $\mathrm{CD} 21^{\text {lo }}$ phenotype (Fig. 3). Increased $\mathrm{CD} 21^{\text {lo }} \mathrm{B}$ cell frequency correlates with disease severity in SLE and RA $[47,48]$. We also found that Jo-1 ARS patients with more severe disease had a trend towards increased frequency of CD21 ${ }^{\text {lo }}$ cells relative to patients with stable disease, despite the small sample size in these subgroups. Given the contrasting potential functionality of CD21 ${ }^{\text {lo }}$ $B$ cells (anergy versus plasma cell precursors), we could not infer function from $C D 21^{\text {lo }}$ phenotype alone in our ex vivo studies. In vitro stimulation drove a lower frequency of JBCs to develop a plasmablast-like phenotype $\left(\mathrm{CD} 38^{\text {hi }} \mathrm{CD} 24^{-}\right)$relative to non-JBCs from the same patient, suggesting JBCs may show some degree of functional impairment, but not enough to prevent at least a subset of JBCs from undergoing IgG class switch and plasmablast differentiation.

$\mathrm{T}$ cells that proliferate to Jo- 1 were found in the peripheral blood of both Jo-1 ARS and healthy controls, suggesting the mere presence of Jo-1-reactive $\mathrm{T}$ cells is insufficient to explain disease pathology; rather, Ascherman et al. postulated interaction with professional antigen-presenting cells is likely necessary to invoke pathologic $\mathrm{T}$ cell responses [49]. IgM-restricted, autoantigen-binding $\mathrm{B}$ cells drive disease in type 1 diabetes-prone mice through their role as antigenpresenting cells, despite their inability to secrete IgG autoantibody $[22,50]$. Thus, autoreactive B cell differentiation into antibody-secreting cells may not be required for their involvement in promoting pathologic autoimmune responses. Human $\operatorname{IgM}^{+} \mathrm{B}$ cells can present antigen to $\mathrm{T}$ cells, including $\mathrm{IgM}^{+} \mathrm{CD} 21^{\mathrm{lo}} \mathrm{B}$ cells isolated from healthy and autoimmune donors [29]. While enrichment of JBCs is increased among $\mathrm{IgG}^{+} \mathrm{B}$ cells, their predominant detection among $\operatorname{IgM}^{+}$B cells suggests non-class-switched JBCs should be considered when designing new immunomodulatory strategies for Jo-1 ARS, as depletion of plasmablasts or plasma cells would not eliminate antigen presentation and activation of $\mathrm{T}$ cells by $\operatorname{IgM}^{+}$(or $\operatorname{IgG}^{+}$) JBCs.

In previous studies, total peripheral blood B cell immunophenotyping in patients with Jo-1 ARS demonstrated a decreased frequency of $\mathrm{CD} 19^{+} \mathrm{CD} 27^{+}$ memory cells (recapitulated here) and increased frequency of naive $B$ cells in the peripheral blood [42]. Interestingly, B cells infiltrating the muscle of IIM patients exhibited both memory and plasma cell phenotypes [12, 42] and showed evidence of somatic hypermutation, selection, and clonal diversification of their B cell receptors [11, 12]. Our analyses, focused specifically on JBCs, show a higher frequency of JBCs is $\mathrm{CD} 21^{\mathrm{lo}} \mathrm{IgM}^{+}$memory B cells compared to nonJBCs from the same Jo-1 ARS patients.

Our findings highlight the propensity of JBCs to enter CD $21^{\text {lo }}$ subsets. CD $21^{\text {lo }} \mathrm{B}$ cells isolated from rheumatic disease patients upregulate costimulatory molecules and drive CD69 upregulation on $\mathrm{T}$ cells, suggesting $\mathrm{CD} 21^{\text {lo }}$ $\mathrm{B}$ cells are competent to present antigen to T cells [29]. It is possible $\mathrm{JBCs}$ identified within $\mathrm{CD} 21^{\mathrm{lo}}$ subsets are competent to present antigen autoreactive $\mathrm{T}$ cells, but this will need to be tested in future work. Detection of JBCs in peripheral blood highlights their potential utility as a biomarker in immunomodulatory clinical trials to allow easy measurement of therapy-induced contraction or phenotypic alteration of autoreactive JBCs.

\section{Conclusions}

Anti-Jo-1 autoantibodies identify the Jo-1 ARS subset of IIM patients. Clinical responses to rituximab implicate $B$ cells in autoimmune pathogenesis. Serologic testing for class-switched Jo-1 autoantibodies identifies Jo-1 ARS patients, but our studies show they do not fully recapitulate the JBC repertoire, as the majority of JBCs have not undergone class switch. These studies define the functional subsets in which JBCs reside to better understand how they expand in Jo-1 ARS patients and highlight their capacity to enter $\mathrm{CD} 21^{\text {lo }}$ and certain memory subsets that are increased in many autoimmune diseases. Our approach also informs the development of future immune therapies; selectively targeting antigen-specific B cells should limit side effects related to broad immune suppression caused by treatments like rituximab. Achieving this goal in Jo-1 ARS requires improved understanding of JBC biology; an optimal approach depends on which functional subset(s) are enriched for this deleterious population of B cells. Additionally, flow cytometry identification of JBCs in Jo-1 ARS patients suggests 
JBCs could be tracked as biomarkers to assess the efficacy of experimental drugs.

\section{Supplementary Information}

The online version contains supplementary material available at https://doi. org/10.1186/s13075-020-02412-8.

\section{Additional file 1}

\section{Abbreviations}

ARS: Anti tRNA synthetase syndrome; BCR: B cell receptor; GST: Glutathione S transferase; Jo-1 ARS: Anti-histidyl-tRNA synthetase syndrome; HRP: Horse radish peroxidase; IIM: Idiopathic inflammatory myopathy; Jo-1: Anti-histidyltRNA synthetase; JBC: Jo-1-binding B cell; MYSTIC: Myositis and Scleroderma Treatment and Investigative Center; PBMCs: Peripheral blood mononuclear cells

\section{Acknowledgements}

We would like to acknowledge the Vanderbilt Institute for Infection, Immunology, and Inflammation.

\section{Authors' contributions}

JYG, AC, EW, and RHB performed experiments and analyzed resulting data. SAS developed the in vitro culture system and provided technical guidance. EW, JYG, and $L C$ recruited patients and assembled the cohort. JYG, AC, and $\mathrm{RHB}$ were major contributors in writing the manuscript. EW, LJC, and RHB provided critical experimental and manuscript feedback. All authors read and approved the final manuscript.

\section{Funding}

National Institutes of Health Grants NIH T32 HL087738, NIH T32 AR059039, and K12 HD 043483, Porter Family Fund for Autoimmunity Research, Vanderbilt Division of Rheumatology and Immunology, Vanderbilt CTSA UL1TR000445, and the Vanderbilt Human Immunology Discovery Initiative supported this work, along with the Vanderbilt Medical Center Flow Cytometry Shared Resource (supported by P30 CA68485, DK058404, P30 EY08126, and G20 RR030956). None of these funding bodies was involved in the design of the study or collection, analysis, and interpretation of data or in writing the manuscript.

\section{Availability of data and materials}

The datasets during and/or analyzed during the current study are available from the corresponding author upon reasonable request.

\section{Ethics approval and consent to participate}

Participants consented to these studies, which were approved by the Vanderbilt Institutional Review Board.

\section{Consent for publication}

Not applicable.

\section{Competing interests}

The authors declare there are no financial or non-financial competing interests to disclose.

\section{Author details}

${ }^{1}$ Department of Medicine, Division of Rheumatology and Immunology, Vanderbilt University Medical Center, Medical Center North T3113, 1161 21st Avenue South, Nashville, TN 37232, USA. ²Department of Medicine, Division of Allergy, Pulmonary, and Critical Care, Vanderbilt University Medical Center, Nashville, TN 37232, USA. ${ }^{3}$ Department of Medicine, Division of Infectious Diseases, Vanderbilt University Medical Center, Nashville, TN 37232, USA. ${ }^{4}$ Department of Pathology, Microbiology and Immunology, Vanderbilt University Medical Center, Nashville, TN 37232, USA.
Received: 22 July 2020 Accepted: 29 December 2020

Published online: 19 January 2021

\section{References}

1. Meyer A, Meyer N, Schaeffer M, Gottenberg J-E, Geny B, Sibilia J. Incidence and prevalence of inflammatory myopathies: a systematic review. Rheumatology (Oxford). 2015;54:50-63.

2. Bohan A, Peter JB. Polymyositis and dermatomyositis (first of two parts). N Engl J Med. 1975:292:344-7.

3. Bohan A, Peter JB. Polymyositis and dermatomyositis (second of two parts). N Engl J Med. 1975;292:403-7.

4. McHugh NJ, Tansley SL. Autoantibodies in myositis. Nat Rev Rheumatol. 2018;14:290-302.

5. Mahler M, Miller FW, Fritzler MJ. Idiopathic inflammatory myopathies and the anti-synthetase syndrome: a comprehensive review. Autoimmun Rev. 2014;13:367-71.

6. Kryštưfková O, Hulejová H, Mann HF, Pecha O, Pưtová I, Ekholm L, et al. Serum levels of B-cell activating factor of the TNF family (BAFF) correlate with anti-Jo1 autoantibodies levels and disease activity in patients with anti-Jo-1 positive polymyositis and dermatomyositis. Arthritis Res Ther. 2018;20:158

7. Sugiura T, Murakawa Y, Nagai A, Kondo M, Kobayashi S. Fas and Fas ligand interaction induces apoptosis in inflammatory myopathies: CD4+ T cells cause muscle cell injury directly in polymyositis. Arthritis Rheum. 1999;42: 291-8.

8. Krystufková O, Vallerskog T, Helmers SB, Mann H, Putová I, Belácek J, et al. Increased serum levels of B cell activating factor (BAFF) in subsets of patients with idiopathic inflammatory myopathies. Ann Rheum Dis. 2009;68: 836-43.

9. Aggarwal R, Oddis CV, Goudeau D, Koontz D, Qi Z, Reed AM, et al. Autoantibody levels in myositis patients correlate with clinical response during B cell depletion with rituximab. Rheumatol (United Kingdom). 2016; 55:991-9.

10. Fasano S, Gordon P, Hajii R, Loyo E, Isenberg DA. Rituximab in the treatment of inflammatory myopathies: a review. Rheumatology. 2017;56: 26-36.

11. Mclntyre D, Zuckerman NS, Field M, Mehr R, Stott DI. The V(H) repertoire and clonal diversification of B cells in inflammatory myopathies. Eur J Immunol. 2014;44:585-96.

12. Bradshaw EM, Orihuela A, McArdel SL, Salajegheh M, Amato AA, Hafler DA, et al. A local antigen-driven humoral response is present in the inflammatory myopathies. J Immunol. 2007;178:547-56.

13. Miller FW, Twitty SA, Biswas T, Plotz PH. Origin and regulation of a diseasespecific autoantibody response. Antigenic epitopes, spectrotype stability, and isotype restriction of anti-Jo-1 autoantibodies. J Clin Invest. 1990:85: 468-75.

14. Martin A, Shulman MJ, Tsui FW. Epitope studies indicate that histidyl-tRNA synthetase is a stimulating antigen in idiopathic myositis. FASEB J. 1995;9: 1226-33.

15. Raben N, Nichols R, Dohlman J, McPhie P, Sridhar V, Hyde C, et al. A motif in human histidyl-tRNA synthetase which is shared among several aminoacyl-tRNA synthetases is a coiled-coil that is essential for enzymatic activity and contains the major autoantigenic epitope. J Biol Chem. 1994; 269:24277-83.

16. O'Hanlon TP, Carrick DM, Targoff IN, Arnett FC, Reveille JD, Carrington M, et al. Immunogenetic risk and protective factors for the idiopathic inflammatory myopathies: distinct HLA-A, -B, -CW, -DRB1, and -DQA1 allelic profiles distinguish European American patients with different myositis autoantibodies. Medicine (Baltimore). 2006;85:111-27.

17. Rothwell S, Chinoy $H$, Lamb JA, Miller FW, Rider LG, Wedderburn LR, et al. Focused HLA analysis in Caucasians with myositis identifies significant associations with autoantibody subgroups. Ann Rheum Dis. 2019;78:9961002

18. Miller FW, Waite KA, Biswas T, Plotz PH. The role of an autoantigen, histidyltRNA synthetase, in the induction and maintenance of autoimmunity. Proc Natl Acad Sci U S A. 1990;87:9933-7.

19. Wurth MA, Hadadianpour A, Horvath DJ, Daniel J, Bogdan O, Goleniewska K, et al. Human IgE mAbs define variability in commercial Aspergillus extract allergen composition. JCl insight. 2018:3:1-10.

20. Isnardi I, Ng Y, Menard L, Meyers G, Saadoun D, Srdanovic I, et al. Complement receptor 2/CD21- human naive B cells contain mostly autoreactive unresponsive clones. Blood. 2010;115:5026-36. 
21. Acevedo-Suárez CA, Hulbert C, Woodward EJ, Thomas JW. Uncoupling of anergy from developmental arrest in anti-insulin B cells supports the development of autoimmune diabetes. J Immunol. 2005;174:827-33.

22. Felton $\mathrm{J}$, Maseda D, Bonami RH, Hulbert C, Thomas JW. Anti-insulin B cells are poised for antigen presentation in type 1 diabetes. J Immunol. 2018;201: 861-73.

23. Goodnow CC, Crosbie J, Adelstein S, Lavoie TB, Smith-Gill SJ, Brink RA, et al. Altered immunoglobulin expression and functional silencing of self-reactive B lymphocytes in transgenic mice. Nature. 1988;334:676-82.

24. Duty JA, Szodoray P, Zheng N-Y, Koelsch KA, Zhang Q, Swiatkowski M, et al. Functional anergy in a subpopulation of naive B cells from healthy humans that express autoreactive immunoglobulin receptors. J Exp Med. 2009;206: 139-51

25. Quách TD, Manjarrez-Orduño N, Adlowitz DG, Silver L, Yang H, Wei C, et al. Anergic responses characterize a large fraction of human autoreactive naive $B$ cells expressing low levels of surface $\operatorname{lgM}$. J Immunol. 2011;186:4640-8.

26. Saadoun D, Terrier B, Bannock J, Vazquez T, Massad C, Kang I, et al. Expansion of autoreactive unresponsive CD21-/low B cells in Sjögren's syndrome-associated lymphoproliferation. Arthritis Rheum. 2013;65:1085-96.

27. Lau D, Lan LY-L, Andrews SF, Henry C, Rojas KT, Neu KE, et al. Low CD21 expression defines a population of recent germinal center graduates primed for plasma cell differentiation. Sci Immunol. 2017;2:139-48.

28. Freudenhammer M, Voll RE, Binder SC, Keller B, Warnatz K. Naive- and memory-like CD21low B cell subsets share core phenotypic and signaling characteristics in systemic autoimmune disorders. J Immunol. 2020;205: 2016-25.

29. Reincke ME, Payne KJ, Harder I, Strohmeier V, Voll RE, Warnatz K, et al. The antigen presenting potential of CD21low B cells. Front Immunol. 2020;11: 535784

30. Glauzy S, Boccitto M, Bannock JM, Delmotte FR, Saadoun D, Cacoub P, et al. Accumulation of antigen-driven lymphoproliferations in complement receptor 2/CD21-/low B cells from patients with Sjögren's syndrome. Arthritis Rheumatol. 2018;70:298-307.

31. Sanz I, Wei C, Jenks SA, Cashman KS, Tipton C, Woodruff MC, et al. Challenges and opportunities for consistent classification of human B cell and plasma cell populations. Front Immunol. 2019;10:2458.

32. Wardemann H. Predominant autoantibody production by early human B cell precursors. Science (80- ). 2003;301:1374-7.

33. Glauzy S, Sng J, Bannock JM, Gottenberg J-E, Korganow A-S, Cacoub P, et al Defective early B cell tolerance checkpoints in Sjögren's syndrome patients. Arthritis Rheumatol (Hoboken, NJ). 2017;69:2203-8.

34. Meffre $E$. The establishment of early $B$ cell tolerance in humans: lessons from primary immunodeficiency diseases. Ann N Y Acad Sci. 2011;1246:110

35. Yurasov S, Wardemann H, Hammersen J, Tsuiji M, Meffre E, Pascual V, et al. Defective B cell tolerance checkpoints in systemic lupus erythematosus. J Exp Med. 2005;201:703-11.

36. Samuels J, Ng Y-S, Coupillaud C, Paget D, Meffre E. Impaired early B cell tolerance in patients with rheumatoid arthritis. J Exp Med. 2005;201:165967.

37. Lee FE-H, Halliley JL, Walsh EE, Moscatiello AP, Kmush BL, Falsey AR, et al. Circulating human antibody-secreting cells during vaccinations and respiratory viral infections are characterized by high specificity and lack of bystander effect. J Immunol. 2011;186:5514-21.

38. Wrammert J, Smith K, Miller J, Langley WA, Kokko K, Larsen C, et al. Rapid cloning of high-affinity human monoclonal antibodies against influenza virus. Nature. 2008;453:667-71.

39. Meffre E, O'Connor KC. Impaired B-cell tolerance checkpoints promote the development of autoimmune diseases and pathogenic autoantibodies. Immunol Rev. 2019;292:90-101.

40. Henry RA, Kendall PL, Thomas JW. Autoantigen-specific B-cell depletion overcomes failed immune tolerance in type 1 diabetes. Diabetes. 2012;61: 2037-44.

41. Ellebrecht CT, Bhoj VG, Nace A, Choi EJ, Mao X, Cho MJ, et al. Reengineering chimeric antigen receptor $T$ cells for targeted therapy of autoimmune disease. Science. 2016;353:179-84

42. Dzangué-Tchoupou G, Allenbach Y, Preuße C, Stenzel W, Benveniste O. Mass cytometry reveals an impairment of B cell homeostasis in antisynthetase syndrome. J Neuroimmunol Elsevier. 2019;332:212-5.
43. Della Valle L, Dohmen SE, Verhagen OJHM, Berkowska MA, Vidarsson G, Ellen van der Schoot $C$. The majority of human memory $B$ cells recognizing RhD and tetanus resides in IgM+ B cells. J Immunol 2014;193:1071-1079.

44. Piper CJM, Wilkinson MGL, Deakin CT, Otto GW, Dowle S, Duurland CL, et al. CD19+CD24hiCD38hi B cells are expanded in juvenile dermatomyositis and exhibit a pro-inflammatory phenotype after activation through toll-like receptor 7 and interferon-a. Front Immunol. 2018;9:1372.

45. Smith MJ, Packard TA, O'Neill SK, Henry Dunand CJ, Huang M, FitzgeraldMiller $L$, et al. Loss of anergic B cells in prediabetic and new-onset type 1 diabetic patients. Diabetes. 2015;64:1703-12.

46. Smith MJ, Rihanek M, Coleman BM, Gottlieb PA, Sarapura VD, Cambier JC Activation of thyroid antigen-reactive $B$ cells in recent onset autoimmune thyroid disease patients. J Autoimmun. 2018;89:82-9.

47. Mensah KA, Chen JW, Schickel J-N, Isnardi I, Yamakawa N, Vega-Loza A, et al. Impaired ATM activation in B cells is associated with bone resorption in rheumatoid arthritis. Sci Transl Med. 2019;11:eaaw4626.

48. Jenks SA, Cashman KS, Zumaquero E, Marigorta UM, Patel AV, Wang X, et al. Distinct effector $B$ cells induced by unregulated toll-like receptor 7 contribute to pathogenic responses in systemic lupus erythematosus. Immunity. 2018;49:725-39 e6.

49. Ascherman DP, Oriss TB, Oddis CV, Wright TM. Critical requirement for professional APCs in eliciting T cell responses to novel fragments of histidyltRNA synthetase (Jo-1) in Jo-1 antibody-positive polymyositis. J Immunol. 2002:169:7127-34

50. Kendall PL, Case JB, Sullivan AM, Holderness JS, Wells KS, Liu E, et al. Tolerant anti-insulin B cells are effective APCs. J Immunol. 2013:190:2519-26.

\section{Publisher's Note}

Springer Nature remains neutral with regard to jurisdictional claims in published maps and institutional affiliations.

Ready to submit your research? Choose BMC and benefit from:

- fast, convenient online submission

- thorough peer review by experienced researchers in your field

- rapid publication on acceptance

- support for research data, including large and complex data types

- gold Open Access which fosters wider collaboration and increased citations

- maximum visibility for your research: over $100 \mathrm{M}$ website views per year

At $\mathrm{BMC}$, research is always in progress.

Learn more biomedcentral.com/submissions 